\title{
Metalloproteinase Inhibitor 4
}

National Cancer Institute

\section{Source}

National Cancer Institute. Metalloproteinase Inhibitor 4. NCI Thesaurus. Code C124088.

Metalloproteinase inhibitor 4 ( $224 \mathrm{aa}, \sim 26 \mathrm{kDa}$ ) is encoded by the human TIMP4 gene.

This protein plays a role in the inhibition of matrix metalloproteinases. 